\title{
Bioconversion of (+)- and (-)-alpha-pinene to (+)- and (-)-verbenone by plant cell cultures of Psychotria brachyceras and Rauvolfia sellowii
}

\author{
Renata Pereira Limberger \\ Programa de Pós-Graduação em Ciências Farmacêuticas \\ Faculdade de Farmácia \\ Universidade Federal do Rio Grande do Sul \\ Av. Ipiranga 2752, 90.610.000 \\ Porto Alegre, RS, Brazil \\ Tel: 555133085297 \\ Fax: 555133085437 \\ E-mail: renata@farmacia.ufrgs.br \\ Adriana Mendes Aleixo \\ Faculdade de Engenharia, Arquitetura e Urbanismo \\ Universidade Metodista de Piracicaba \\ Rodovia Santa Bárbara Iracemápolis Km 1, 13450-000 \\ Santa Barbara D'oeste, SP, Brazil \\ Tel: 1931241782 \\ E-mail: amaleixo@unimep.br \\ Arthur Germano Fett-Neto \\ Programa de Pós-Graduação em Biologia Celular e Molecular \\ Centro de Biotecnologia \\ Universidade Federal do Rio Grande do Sul \\ CP 15005 Agronomia, 91509-900 \\ Porto Alegre, RS - Brazil \\ Tel: 5133087642 \\ Fax: 5133087309 \\ E-mail: fettneto@cbiot.ufrgs.br \\ Amélia T. Henriques*

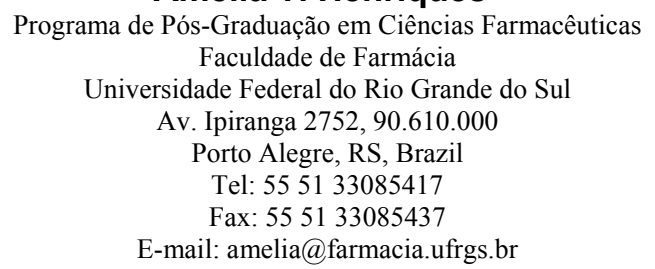

Financial support: CNPq, CAPES and FAPERGS.

Keywords: alpha-pinene, biotransformation, verbenol, verbenone.

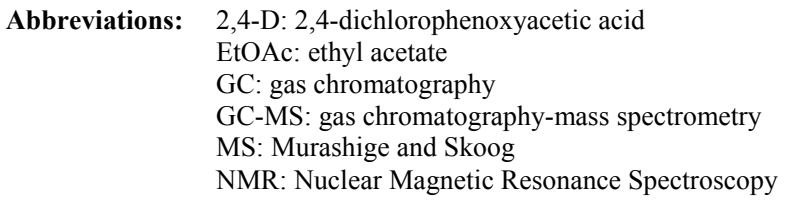

This work describes the bioconversion of (-)- and (+)alpha-pinene (2,6,6-trimethyl-bicyclo[3.1.1] hept-2-ene), targeted at the production of (-)- and $(+)$-verbenone (4,6,6-trimethyl-bicyclo (3.1.1) hept-3-en-2-one), respectively, using Psychotria brachyceras and Rauvolfia sellowii cell suspension cultures. $P$. brachyceras showed selectivity to (-)-alpha-pinene with $\mathbf{8 0 . 9 \%}$ conversion (relative integrated area gas chromatography -mass spectrometry (GC -MS)) of (-)-verbenone in 10-dayincubation, whereas $R$. sellowii was able to convert both pinene enantiomers $(37.6 \%$ conversion of $(-)$-verbenone in 7-day-incubation and $32.2 \%$ conversion of (+)verbenone in 10-day-incubation). In both systems transverbenol was formed as main product and then slowly biocatalyzed to verbenone. Verbenone were also present among the autoxidation products during control

*Corresponding author 
experiments, but in much lower amounts and accompanied by several by-products, highlighting the usefulness of the biotransformation process.

The exploration of inexpensive and abundantly available terpenoids, widely distributed in nature and produced in bulk amounts, for the biotechnological production of valueadded compounds using biotransformation approaches drives special interest for the production of natural flavors and fragrances due to their distinctive and pleasant odors, as well as taste notes. Moreover, several processes in chemical synthesis also use terpenoids due their particularly stereochemistry.

Alpha-Pinene is the major constituent of the turpentine oils from most conifers and a component of the wood and leaf oils obtained from leaves, bark, and wood of a wide variety of other plants. In Brazil, the pine resin tapping activity is increasingly important, producing resin mostly for export; $100,000.00$ tons were produced in 2002, a market that moved some US\$ 25 millions, providing over 12,000.00 direct jobs in the countryside (source: Brazilian Association of Resin Extraction http://www.aresb.com.br/estatisticas/index.htm in december 2006). In order to increase the commercial value of the turpentine oil, it would be of interest to convert alphapinene into more valuable compounds. Selective oxidation of alpha-pinene with some biocatalysts can yield valueadded products, such as verbenone and verbenol, antiaggregation and aggregation pheromones, respectively, that are used in the control of southern pine beetle infestations, particularly of the genera Tomicus (Hylesininae), Ips e Dendroctonus (Scolytinae) (Huber and Borden, 2001; Lindgren and Miller, 2002; Díaz-Nuñez et al. 2006). (+)-verbenone is a particularly attractive starting material used in asymmetric synthesis, as chiral precursor to the preparation of the A-ring subunit of the antitumoral diterpene taxol ${ }^{\circledR}$ (Lajunen et al. 2000). (-)-verbenone is a major flavor constituent of strawberry, raspberry, dill, rosmarinus and spearmint flavor mixtures with high demand in the food industry (Ravid et al. 1997) and, more

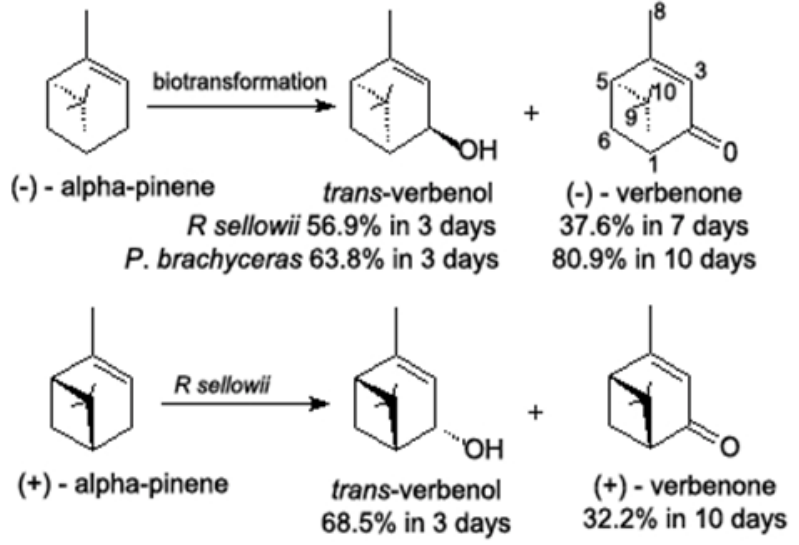

Figure 1. Biotransformations of alpha-pinene carried out by Psychotria brachyceras and Rauvolfia sellowii.

recently, has been used as starting material to prepare cyclobutyl GABA analogues (Moglioni et al. 2002) and cyclobutane carbocyclic nucleoside and oligopeptides (Rouge et al. 2003).

Over the past few decades a large number of biotransformations of alpha-pinene into verbenone has been reported using fungi: Aspergillus niger (Agrawal and Joseph, 2000; Divyashree et al. 2006), Hormonema sp. (van Dyk et al. 1998) and Botrytis cinerea (Farooq et al. 2002); bacteria: Serratia marcescens (Wright et al. 1986), Pseudomonas spp. (Divyashree et al. 2006) and Nocardia sp. (Perez et al. 1999); and plant cell suspension cultures: Nicotiana tabacum, Cannabis sativa (Hirata et al. 1994) and Picea abies (Lindmark-Henriksson et al. 2003; Vanek et al. 2005). However, selectivity coupled to improved yields is highly desirable to make industrial applications feasible. On the basis of these considerations, the objective of the present work was to find systems able to convert alpha-pinene (2,6,6-trimethyl-bicyclo[3.1.1]hept-2-ene) into verbenone (4,6,6-trimethyl-bicyclo (3.1.1) hept-3-en-2one), using a biotransformation approach based on

Table 1. Bioconversion of (-)-alpha-pinene $(60 \mathrm{mg})$ by Psychotria brachyceras $(30 \mathrm{~g}$ fresh weight). Numbers represent mean percentages \pm standard deviation (four replications) of components starting with $100 \%$ alpha-pinene at the experimental onset.

\begin{tabular}{|l|c|c|c|c|c|c|}
\hline & Day 1 & Day 3 & Day 5 & Day 7 & Day 10 & Day 15 \\
\hline (-)-alpha-pinene & $\mathbf{1 . 0 \pm 0 . 9}$ & $\mathbf{0 . 5} \mathbf{0 . 4}$ & $\mathbf{0 . 7} \pm \mathbf{0 . 4}$ & $\mathbf{0 . 0}$ & $\mathbf{0 . 0}$ & $\mathbf{0 . 0}$ \\
\hline trans-pinocarveol & $3.3 \pm 0.6$ & $2.1 \pm 0.5$ & $2.7 \pm 0.6$ & $1.9 \pm 0.6$ & 0.0 & $2.6 \pm 1.5$ \\
\hline trans-verbenol & $73.7 \pm 4.8$ & $63.8 \pm 1.3$ & $59.1 \pm 3.6$ & $37.1 \pm 6.8$ & $15.7 \pm 3.8$ & $17.2 \pm 2.2$ \\
\hline myrtenol & $9.5 \pm 3.6$ & $9.6 \pm 0.7$ & $8.3 \pm 1.1$ & $3.5 \pm 1.3$ & $1.8 \pm 3.6$ & $2.1 \pm 2.0$ \\
\hline (-)-verbenone & $\mathbf{1 0 . 7 \pm 1 . 9}$ & $\mathbf{1 9 . 5 \pm \mathbf { 4 . 2 }}$ & $\mathbf{2 2 . 0 \pm \mathbf { 3 . 6 }}$ & $\mathbf{4 8 . 4 \pm \mathbf { 5 . 9 }}$ & $\mathbf{8 0 . 9} \mathbf{2 . 9}$ & $\mathbf{7 6 . 3} \mathbf{\mathbf { 1 . 5 }}$ \\
\hline
\end{tabular}




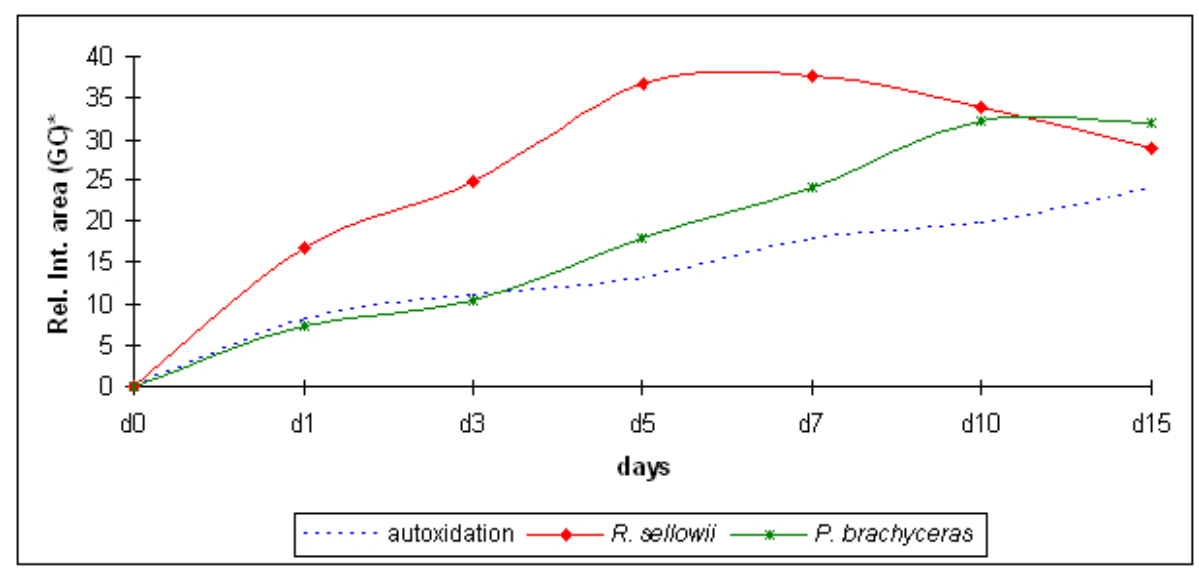

Figure 2. Biotransformation of (-)-alpha-pinene to (-)-verbenone carried out by Rauvolfia sellowii and Psychotria brachyceras cell suspension cultures, compared with that observed in control experiments. *Integrated peak area (GC-MS) relative to total integrated area in percent. The differences in response factors were neglected.

exploration of biocatalytic potential of native plant cell suspension cultures. By using such procedures, the desirable classification of natural is assured and larger amounts of substrates and products can be tolerated by the biocatalyst. In microbiological approaches, the toxicity of the substrate and product often represent limiting problems for the scaling up processes. This investigation is focused on the qualitative product pattern obtained, rather than on the absolute yields of the various products and the mass balances between substrates and products, in order to select a substrate-biocatalyst pair for further detailed applied studies.

\section{MATERIALS AND METHODS}

\section{Substrate}

$(1 S, 5 R)-(-)$-alpha-pinene and $(1 R, 5 S)-(+)$-alpha-pinene were purchased from Merck (Darmstadt, Germany).
$(1 S, 5 S)-(-)$-verbenone was purchased from Sigma-Aldrich Chemical Co. (St. Louis, USA).

\section{Cell culture stocks}

The callus tissues of $P$. brachyceras Müll Arg. (Rubiaceae) used in this investigation were induced from young stem segments (developed under indoor conditions) of cuttings cultured in nutrient solution, as described by Gregianini et al. (2003). After surface sterilization using standard procedures, stem segments were cultured under darkness in MS (Murashige and Skoog) medium containing 3\% w/v of sucrose, $1 \% \mathrm{w} / \mathrm{v}$ soluble polyvinylpolypyrrolidone (PVP), $0.75 \% \mathrm{w} / \mathrm{v}$ microbiological grade agar, $10 \mathrm{mg} / \mathrm{l}$ of naphthaleneacetic acid (NAA, Sigma Chemical Co. St. Louis, USA) and $1 \mathrm{mg} / \mathrm{l}$ kinetin (KIN, Sigma Chemical Co. St. Louis, USA). Calli were developed and maintained in this medium with monthly subcultures at the Laboratory of Plant Physiology, UFRGS. A voucher of the plant, which

Table 2. Bioconversion of (-)-alpha-pinene $(60 \mathrm{mg})$ by Rauvolfia sellowii (30 $\mathrm{g}$ fresh weight). Numbers represent mean percentages \pm standard deviation (four replications) of components starting with $100 \%$ alpha-pinene at the experimental onset.

\begin{tabular}{|c|c|c|c|c|c|c|}
\hline & Day 1 & Day 3 & Day 5 & Day 7 & Day 10 & Day 15 \\
\hline (-)-alpha-pinene & $11.9 \pm 1.3$ & $6.1 \pm 1.4$ & $2.0 \pm 2.6$ & 0.0 & 0.0 & 0.0 \\
\hline trans-pinocarveol & $10.4 \pm 4.4$ & $6.4 \pm 2.4$ & $6.2 \pm 3.1$ & $11.0 \pm 1.4$ & $10.5 \pm 0.6$ & $13.5 \pm 2.4$ \\
\hline trans-verbenol & $50.6 \pm 7.0$ & $56.9 \pm 4.3$ & $46.4 \pm 3.5$ & $41.4 \pm 2.5$ & $40.2 \pm 5.1$ & $38.4 \pm 0.8$ \\
\hline trans-pinanone & 0.0 & $0.7 \pm 1.6$ & $0.5 \pm 1.2$ & $5.6 \pm 1.3$ & $7.5 \pm 1.7$ & $8.6 \pm 1.8$ \\
\hline myrtenol & $5.3 \pm 0.9$ & $4.2 \pm 1.9$ & $4.3 \pm 2.4$ & $6.5 \pm 0.6$ & $7.0 \pm 0.4$ & $6.4 \pm 1.2$ \\
\hline (-)-verbenone & $16.7 \pm 1.1$ & $24.6 \pm 3.0$ & $36.6 \pm 6.9$ & $37.6 \pm 1.8$ & $33.9 \pm 4.3$ & $28.9 \pm 3.4$ \\
\hline
\end{tabular}




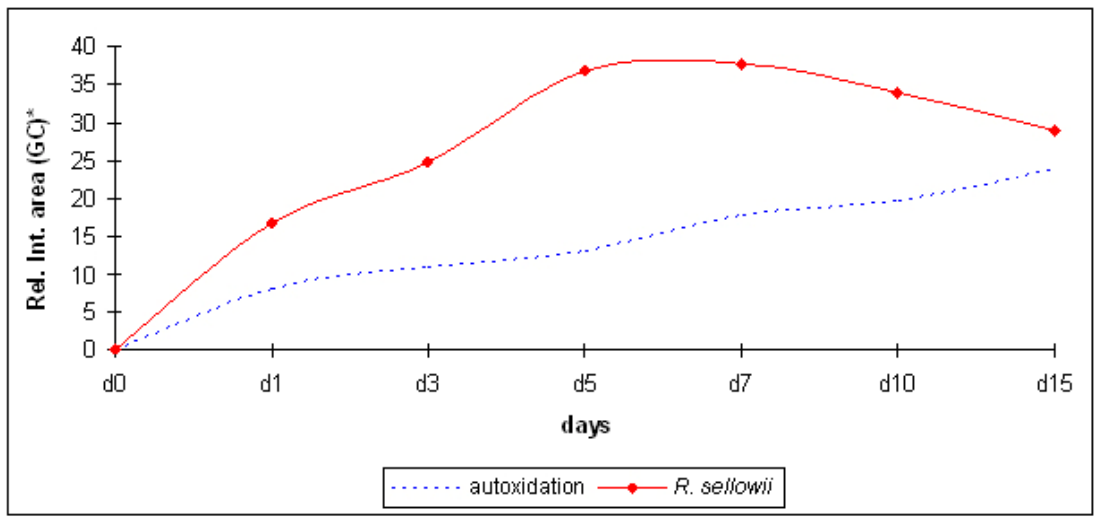

Figure 3. Biotransformation of (+)-alpha-pinene to (+)-verbenone carried out by Rauvolfia sellowii cell suspension culture, compared with that observed in control experiments. *Integrated peak area (GC-MS) relative to total integrated area in percent. The differences in response factors were neglected.

was harvested at Morro Santana (campus of UFRGS, Porto Alegre, RS, Brazil), is deposited in the University Herbarium (ICN Sobral and Kerber 7899). Cell suspension cultures of $R$. sellowii Müll Arg. (Apocynaceae) were originally developed by Rech et al. (1998) and maintained on B5 (Gamborg) medium containing $1 \mathrm{mg} / \mathrm{l}$ of 2,4dichlorophenoxyacetic acid (2,4-D, Sigma Chemical Co. St. Louis, USA) and 4\% w/v sucrose. Suspension cultures were maintained in this medium, being transferred onto fresh medium fortnightly.

\section{Biotransformations}

Biotransformations of (1S,5R)-(-)-alpha-pinene and $(1 R, 5 S)-(+)$-alpha-pinene were carried out by Psychotria brachyceras and Rauvolfia sellowii cell suspension cultures. Before each experiment, ca. $30 \mathrm{~g}$ of cells or callus tissue were transferred to a $250 \mathrm{ml}$ conical flask containing $30 \mathrm{ml}$ of freshly prepared SH medium (Schenk and Hildebrandt, 1972) containing $1 \mathrm{mg} / \mathrm{l}$ of 2,4-D and $3 \% \mathrm{w} / \mathrm{v}$ sucrose. Cells were then grown for 1 week at $25 \pm 2^{\circ} \mathrm{C}$, under diffuse light $\left(3 \mu \mathrm{mol} . \mathrm{s}^{-1} \cdot \mathrm{m}^{2}\right)$, on a rotary shaker $(100$ $\mathrm{rpm})$. After this time, $1.0 \mathrm{ml}$ of a methanolic solution (60 $\mathrm{mg} / \mathrm{ml}$ ) of substrate, without prior sterilization, was added to the cell suspensions, and the cultures were returned to the shaker for 15 days. Controls were prepared by the addition of $1 \mathrm{ml}$ of a methanolic solution $(60 \mathrm{mg} / \mathrm{ml})$ of alpha-pinene to $30 \mathrm{ml}$ of medium, and, in other flasks, ca. $30.0 \mathrm{~g}$ cells and $30 \mathrm{ml}$ medium. Experiments (each with four replicates per sampling time) were independently repeated three times with similar results.

\section{Extraction and analysis}

For optimization of extraction procedure, portions of the incubation mixture were pipetted out and extracted with different polarity solvents, such as hexane, chloroform and ethyl acetate (EtOAc), in order to establish the best solvent to extraction procedure. A reminiscent strong emulsion could be observed by the use of EtOAc, even after treatment with sodium chloride-saturated aqueous solution and centrifugation steps, giving samples with a lower concentration of products than that obtained using the other solvents. When the chloroform and hexane were used as solvent, a good performance could be observed, resulting samples with qualitatively equivalent compounds. The exchange of the solvent chloroform to hexane did not change the quantity of obtained monoterpenes. In addition, the use of hexane to the time course analyses reduced another disadvantage associated with the use of chloroform, as the water and medium components solubility being lower in hexane than in chloroform; and the use of hexane extend the lifetime of the water-sensitive chiral gas chromatography (GC) columns that we employed for our analyses. Besides that, hexane afforded more environmentally benign conditions. Even so, for the time course analysis, at the desired time intervals, $10 \mathrm{ml}$ portions of the incubation mixture were harvested from quadruplicate flasks, vigorous shaking, and extracted with 5 $\mathrm{ml}$ of hexane. The organic fraction was dried over sodium sulphate, filtered and evaporated under vacuum. The residue obtained was made up to $1 \mathrm{ml}$ with hexane and $3 \mathrm{ml}$ of the solution was subjected to gas chromatography-mass spectrometry (GC-MS) to the qualitative analysis and to GC with flame ionization detector (FID) detector to the quantitative analysis. To the confirmatory studies, the crude extract were saturated with sodium chloride-saturated aqueous solution, extracted with chloroform, evaporated to dryness under reduced pressure and purified by column chromatography on silica gel (70-230 mesh - Aldrich) using as mobile phase hexane:EtOAc (90:10 and 80:20), collecting $10 \mathrm{ml}$ fractions, to give verbenones as yellow oils.

Gas Chromatography analyses were performed using a Shimadzu GC-17A chromatograph equipped with a fused silica capillary column $(30 \mathrm{~m} \times 0.25 \mathrm{~mm} \times 0.25 \mathrm{~mm}$, coated with DB-5). Injector and detector temperatures were set at $220^{\circ} \mathrm{C}$ and $250^{\circ} \mathrm{C}$, respectively; the oven temperature was programmed from $60-230^{\circ} \mathrm{C}$ at $3^{\circ} \mathrm{C} / \mathrm{min}$. All the samples 
were analyzed by GC-MS in the same apparatus and chromatographic conditions as described above, using a quadrupole MS system (QP 5000) operating at $70 \mathrm{eV}$. The percentage composition of unreacted substrate and the amount of products were obtained from electronic integration measurements using flame ionization detection, without taking into account relative response factors. Compounds identification was based on a comparison of retention indexes (determined relatively to the retention times of a series of $n$-alkanes) and mass spectra with those of authentic standard purchased from Sigma-Aldrich and literature data (van Dyk et al. 1998; Adams, 2001). The retention indexes obtained were 945 to alpha-pinene, 1132 to trans-pinocarveol, 1140 to trans-verbenol, 1189 to myrtenol, 1199 to unidentified, and 1202 to verbenone. Chiral Gas Chromatography analyses were carried out using the same GC-MS system, equipped with a chiral betacyclodextrin $(30 \mathrm{~m} \times 0.25 \mathrm{~mm} \times 0.25 \mu \mathrm{m}$, coated with BCDEX 120) fused silica capillary column. The oven temperature was programmed from $60-220^{\circ} \mathrm{C}$ at $3^{\circ} \mathrm{C} / \mathrm{min}$. Injector and detector temperatures were set at $200^{\circ} \mathrm{C}$ and $230^{\circ} \mathrm{C}$, respectively. Helium was employed as carrier gas $(1$ $\mathrm{ml} / \mathrm{min}$ ). Under these conditions, the retention times obtained were $10.071 \mathrm{~min}$ to (-)-alpha-pinene, $10.338 \mathrm{~min}$ to (+)-alpha-pinene, $27.858 \mathrm{~min}$ to (-)-verbenone, and $28.033 \mathrm{~min}$ to $(+)$-verbenone. In the confirmatory studies, the purified verbenones were identified by physical data comparison with authentic samples purchased from SigmaAldrich based on a comparison of $[\alpha]_{\mathrm{D}}$ values and Nuclear Magnetic Resonance Spectroscopy (NMR) chemical shifts (reported in ppm) and compared with previously reported data (van Dyk et al. 1998; Lajunen et al. 2000). The optical rotation values of purified verbenones $\left([\alpha]_{\mathrm{D}}{ }^{20}=-258^{\circ}\right.$ to (-)verbenone and $+258^{\circ}$ to $(+)$-verbenone, $\left.c 1.0, \mathrm{CHCl}_{3}\right)$, were measured with a Perkin Elmer 341 Polarimeter. The NMR spectra were obtained on a Varian VXR200 apparatus, using $\mathrm{CDCl}_{3}$ as an internal standard. ${ }^{1} \mathrm{H}$ NMR. $(200 \mathrm{MHz}$, $\left.\mathrm{CDCl}_{3}\right) \delta: 1.02$ (s, 3H, H-9); 1.47 (s, 3H, H-10); 2.00 (d, 3H, $\mathrm{J}=1,5 \mathrm{~Hz}, \mathrm{H}-8) ; 2.10-2.08$ (m, 1H, H-6); $2.42(\mathrm{~m}, 1 \mathrm{H}, \mathrm{H}-$ 5); $2.70-2.62(\mathrm{~m}, 1 \mathrm{H}, \mathrm{H}-1) ; 2.91-2.80(\mathrm{~m}, 1 \mathrm{H}, \mathrm{H}-6) ; 5.71$ (m, 1H, H-3). ${ }^{13} \mathrm{C}$ RMN. $\left(50.0 \mathrm{MHz}, \mathrm{CDCl}_{3} \delta\right.$; )) 22.0 (C-9); 23.3 (C-8); 26.7 (C-10); 40.8 (C-7); 49.7 (C-5); 53.8, (C-6); 57.6 (C-1); 121.4 (C-3); 170.0 (C-4); 203.9 (C-2).

\section{RESULTS AND DISCUSSION}

Biotransformations of (-)-alpha-pinene and (+)-alphapinene were carried out in order to achieve (-)- and (+)verbenone formation, by the use of Psychotria brachyceras and Rauvolfia sellowii cell suspension cultures. The cultures were selected due to our interest in explore the potential of native plant cell suspension cultures. The stereochemistry of stereogenic center were evaluated by chiral GC coinjection with commercial samples purchased from Sigma-Aldrich and confirmed by $[\alpha]$ values from purified verbenones. The results showed that under the evaluated conditions, $P$. brachyceras was able to modify only the (-)-enantiomer, whereas $R$. sellowii was effective towards both enantiomers of alpha-pinene with similar profile. When the $(+)$-alpha-pinene were added to the $P$. brachyceras suspension cultures, the substrate was completely consumed and no further products could be observed. The reactions were characterized mainly by oxidation at the allylic position affording trans-verbenol, following by slow oxidation to verbenone (Figure 1). transPinocarveol, cis-verbenol and myrtenol were identified as minor products. Verbenone and trans-verbenol, together with myrtenol and trans-pinocarveol, have previously been described as major alpha-pinene biotransformation products formed by other biocatalysts (Hirata et al. 1994; van Dyk et

Table 3. Bioconversion of $(+)$-alpha-pinene $(60 \mathrm{mg})$ by Rauvolfia sellowii $(30 \mathrm{~g}$ fresh weight). Numbers represent mean percentages \pm standard deviation (four replications) of components starting with $100 \%$ alpha-pinene at the experimental onset.

\begin{tabular}{|c|c|c|c|c|c|c|}
\hline & Day 1 & Day 3 & Day 5 & Day 7 & Day 10 & Day 15 \\
\hline (+)-alpha-pinene & $25.9 \pm 8.3$ & $3.7 \pm 2.2$ & $3.2 \pm 1.8$ & 0.0 & 0.0 & 0.0 \\
\hline trans-pinocarveol & $7.3 \pm 0.5$ & $8.5 \pm 2.8$ & $7.0 \pm 3.2$ & $7.5 \pm 5.5$ & $7.8 \pm 2.9$ & $12.2 \pm 1.9$ \\
\hline trans-verbenol & $54.5 \pm 6.9$ & $68.5 \pm 3.0$ & $61.7 \pm 4.3$ & $59.1 \pm 4.4$ & $48.0 \pm 2.0$ & $39.1 \pm 1.5$ \\
\hline myrtenol & $2.3 \pm 0.7$ & $3.2 \pm 1.7$ & $4.6 \pm 1.9$ & $3.8 \pm 2.5$ & $2.2 \pm 0.8$ & $2.9 \pm 0.8$ \\
\hline unidentified ${ }^{*}$ & $2.2 \pm 1.2$ & $4.7 \pm 3.1$ & $4.8 \pm 2.7$ & $3.1 \pm 4.2$ & $3.4 \pm 1.1$ & $4.3 \pm 3.0$ \\
\hline (+)-verbenone & $7.4 \pm 1.2$ & $10.4 \pm 2.0$ & $17.9 \pm 3.2$ & $24.0 \pm 2.1$ & $32.2 \pm 0.7$ & $31.9 \pm 3.1$ \\
\hline
\end{tabular}

${ }^{*} \mathrm{~m} / \mathrm{z}=95(100) ; 41(47.1) ; 93(25.2) ; 43(21.5) ; 55(17.4) ; 79(14.1) ; 67(13.9) ; 91(13.7) ; 121(13.4) ; 105(12.5) ; 53(11.6) ; 77(10.7) ;$ 81(7.8); 110(7.8); 139(6.5); 136(4.6); 154(2.8). 
Table 4. Degradation of (-)-alpha-pinene $(1,0 \mathrm{ml}$ of a methanolic solution of $50 \mathrm{mg} / \mathrm{ml})$ in reaction medium $(50 \mathrm{ml})$. Similar profiles were obtained with $50 \mathrm{~mL}$ of the following types of solvents evaluated separately: distilled water, Milli-Q® water, phosphate buffer, MS medium prepared with Milli- $Q \circledR$ water, or MS medium prepared with distilled water. Numbers represent mean percentages \pm standard deviation (four replications) of components starting with $100 \%$ alpha-pinene at the experimental onset.

\begin{tabular}{|l|c|c|c|c|c|c|c|}
\hline & $\mathbf{3 ~ h r s}$ & Day 1 & Day 3 & Day 5 & Day 7 & Day 10 & Day 15 \\
\hline (-)-alpha-pinene & $\mathbf{2 . 2} \pm \mathbf{1 . 3}$ & $\mathbf{0 . 0}$ & $\mathbf{0 . 0}$ & $\mathbf{0 . 0}$ & $\mathbf{0 . 0}$ & $\mathbf{0 . 0}$ & $\mathbf{0 . 0}$ \\
\hline campholenal & $7.2 \pm 2.5$ & $3.2 \pm 0.9$ & $2.0 \pm 0.9$ & $1.5 \pm 0.6$ & $0.8 \pm 0.2$ & $1.6 \pm 0.4$ & $0.2 \pm 0.1$ \\
\hline trans-pinocarveol & $10.9 \pm 3.7$ & $6.5 \pm 2.7$ & $5.6 \pm 2.3$ & $4.4 \pm 0.8$ & $3.1 \pm 1.7$ & $3.0 \pm 1.4$ & $1.0 \pm 0.3$ \\
\hline cis-verbenol & $2.1 \pm 0.5$ & $2.3 \pm 1.3$ & $3.1 \pm 0.8$ & $2.7 \pm 1.0$ & $2.0 \pm 1.4$ & $2.9 \pm 0.4$ & $2.7 \pm 0.1$ \\
\hline trans-verbenol & $\mathbf{6 2 . 5} \mathbf{3 . 5}$ & $\mathbf{6 4 . 6 \pm 6 . 0}$ & $\mathbf{6 7 . 5} \pm \mathbf{2 . 9}$ & $\mathbf{6 7 . 6} \pm \mathbf{2 . 4}$ & $\mathbf{6 4 . 6 \pm 2 . 4}$ & $\mathbf{5 9 . 4} \pm \mathbf{1 . 6}$ & $\mathbf{6 0 . 0} \pm \mathbf{2 . 5}$ \\
\hline myrtenol & $6.7 \pm 2.5$ & $6.1 \pm 1.2$ & $6.6 \pm 0.5$ & $6.5 \pm 0.6$ & $6.0 \pm 0.5$ & $6.5 \pm 0.5$ & $6.9 \pm 0.4$ \\
\hline (-)-verbenone & $7.6 \pm 0.8$ & $8.1 \pm 1.3$ & $10.9 \pm 0.8$ & $12.9 \pm 0.7$ & $17.6 \pm 2.2$ & $19.6 \pm 1.3$ & $23.8 \pm 0.3$ \\
\hline myrtanol & $2.3 \pm 1.5$ & $1.7 \pm 0.9$ & $2.1 \pm 0.3$ & $2.2 \pm 0.4$ & $2.7 \pm 0.6$ & $2.6 \pm 0.2$ & $2.7 \pm 0.3$ \\
\hline
\end{tabular}

al. 1998; Lindmark-Henriksson et al. 2003). Enantioselectivity has previously been found in biotransformations of (-)-alpha-pinene (Hirata et al. 1994; Farooq et al. 2002) and (+)-alpha-pinene (Agrawal and Joseph, 2000). However, Lindmark-Henriksson et al. (2003) found little or no selectivity of Picea abies cell suspensions in the transformations of alpha-pinene; the authors suggested that this lack of specificity could reflect a transformation via a radical mechanism with possible involvement of peroxidases in the reactions. This might also be the case of $R$. sellowii.

The time courses analysis of bioconversion of alphapinenes by $P$. brachyceras and $R$. sellowii are shown in Table 1 to Table 3. Values correspond to the overall mean concentrations \pm standard deviations (since individual means did not differ between themselves) obtained in three independent experiments carried out in quadruplicates. $P$. brachyceras afforded the best results, achieving $80.9 \%$ conversion (relative integrated area GC-MS) of (-)-alphapinene to (-)-verbenone after a 10-day-incubation (Table 1). $R$. sellowii was less efficient for the production of (-)verbenone $(37.6 \%$ conversion in 7-day-incybation - Table 2 ), when compared with $P$. brachyceras, but showed the ability to convert (+)-alpha-pinene, with (+)-verbenone peaking at $32.2 \%$ conversion on day 10 (Table 3 ).

Control experiments, in which both enantiomers of alphapinene were added to culture medium, as well as suspension cultures not supplemented with substrate, were carried out for all incubation periods. In control flasks containing only cells and medium, no monoterpene metabolites could be detected, whereas in the control flasks supplemented with substrate, but devoid of biocatalyst cells, a quick conversion to a variety of autoxidation products was observed (Table 4). The autoxidation products were characterized by proceeding with a wider range of compounds. For instance, the formation of verbenone has also been found among the autoxidation products of alphapinenes, nevertheless, this amount was much smaller than the amount of verbenone produced from the same substrates by the cell suspension cultures, under the same conditions and time (Figure 2 and Figure 3). Thus, in the presence of biocatalyst, a greater extent of this ketone was produced, being the bioconversion increased by almost 2 fold with $R$. sellowii and more than 4 fold with $P$. brachyceras. The results are in agreement to those reported by Lindmark-Henriksson et al. (2003), which had also been observed that verbenone, verbenol and sobrerol were found among the autoxidation products of alpha-pinene. The authors also report that alpha-pinene subjected to the $P$. abies suspension culture, yielded a product containing mainly trans-verbenol, which when subjected to the nutrient medium alone, undergoes autoxidation to give much less of a product with verbenone as the major component. The comparison of verbenone contents obtained by the degradation of (-)-alpha-pinene in the control experiments and by $R$. sellowii and $P$. brachyceras (Figure 2) shows the efficiency of cell suspensions of $P$. brachyceras to produce high conversion rates of (-)verbenone in enantioselective fashion.

\section{CONCLUDING REMARKS}

$R$. sellowii and $P$. brachyceras were able to convert alphapinene into verbenone without changes in the stereogenic center of the molecules. The verbenone was also present among the autoxidation products, but in much lower 
Bioconversion of (+)- and (-)-alpha-pinene to (+)- and (-)-verbenone by plant cell cultures of

amounts under the same conditions and time, highlighting the usefulness of the biotransformation process. $P$. brachyceras work in a selective way, affording the flavorant (-)-verbenone with high conversion rates. It is clearly interesting and could be considered as an alternative to direct and selective obtaining of (-)-verbenone in futures scaling up processes. A different behavior was observed with $R$. sellowii, which was characterized by giving relatively lower production of (-)-verbenone than that found with $P$. brachyceras, with little or no enantioseletivity. However $R$. sellowii was able to convert the antipode $(+)-$ alpha-pinene into $(+)$-verbenone, a particularly attractive starting material for asymmetric synthesis. The importance of these findings is heightened by the natural status of biocatalytic processes and the lack of synthetic methods with equivalent efficiencies in the production of optical pure verbenone. Natural verbenone is currently obtained by extraction from pine and eucalyptus sources with great demand in the food industry for use as the main component of several flavors (Ravid et al. 1997); market prices of verbenone are much higher than those of pinene, suggesting economic viability (Agrawal and Joseph, 2000).

\section{REFERENCES}

ADAMS, Robert P. Identification of essential oil components by gas chromatography/quadrupole mass spectrometry. Carol Stream, Allured Publishing Corp., 2001, 456 p. ISBN 0-931710-85-5.

AGRAWAL, Renu and JOSEPH, Richard. Bioconversion of alpha-pinene to verbenone by resting cells of Aspergillus niger. Applied Microbiology and Biotechnology, March 2000, vol. 53, no. 3, p. 335-337.

DIAZ-NUÑEZ, Vicente; SANCHEZ-MARTINEZ, Guillermo and GILLETTE, Nancy E. Response of Dendroctonus mexicanus (Hopkins) to two optical isomers of verbenone. Agrociencia, May 2006, vol. 40, no. 3, p. 349-354.

DIVYASHREE, M.S.; GEORGE, J. and AGRAWAL, R. Biotransformation of terpenic substrates by resting cells of Aspergillus niger and Pseudomonas putida isolates. Journal of Food Science and Technology, January 2006, vol. 43, no. 1, p. 73-76.

FAROOQ, Afgan; TAHARA, Satoshi; CHOUDHARY, M. Iqbal; ATTA-UR-RAHMAN; AHMED, Zafar; BASER, K. Hüsnü Can and DEMIRCI, Fatih. Biotransformation of (-)alpha-pinene by Botrytis cinerea. Zeitschrift für Naturforschung C, January 2002, vol. 57c, no. 3-4, p. 303306.

GREGIANINI, Tatiana S.; SILVEIRA, Vivian C. da; PORTO, Diogo D.; KERBER, Vitor A.; HENRIQUES, Amélia T. and FETT-NETO, Arthur G. The alkaloid brachycerine is induced by ultraviolet radiation and is a singlet oxygen quencher. Photochemistry and Photobiology, November 2003, vol. 78, no. 5, p. 470-474.

HIRATA, Toshifumi; IKEDA, Yoshihiro; IZUMI, Shunsuke; SHIMODA, Kei; HAMADA, Hiroki and KAWAMURA, Toshinari. Introduction of oxigenated functional groups into 3-carene and 2-pinene by cultured cells. Phytochemistry, September 1994, vol. 37, no. 2, p. 401-403.

HUBER, D.P.W. and BORDEN, J.H. Protection of lodgepole pines from mass attack by mountain pine beetle, Dendroctonus ponderosae, with nonhost angiosperm volatiles and verbenone. Entomologia Experimentalis et Applicata, May 2001, vol. 99, no. 2, p. 131-141.

LAJUNEN, Marja K.; MAUNULA, Tatja and KOSKINEN, Ari M.P. Co(II) catalyzed oxidation of alphapinene by molecular oxygen. Part 2. Tetrahedron, October 2000 , vol. 56 , no. 41 , p. $8167-8171$.

LINDGREN, B. Staffan and MILLER, Daniel R. Effect of verbenone on five species of Bark Beetles (Coleoptera: Scolytidae) in Lodgepole Pine Forests. Environmental Entomology, October 2002, vol. 31, no. 5, p. 759-765.

LINDMARK-HENRIKSSON, Marica; ISAKSSON, Dan; SJÖDIN, Kristina; HÖGBERG, Hans-Erik; VANEK, Tomáš and VALTEROVÁ, Irena. Transformation of $\alpha$ pinene using Picea abies suspension culture. Journal of Natural Products, February 2003, vol. 66, no. 3, p. 337343.

MOGLIONI, Albertina G.; BROUSSE, Beatriz N.; ALVAREZ-LARENA, Angel; MOLTRASIO, Graciela Y. and ORTUÑO, Rosa M. Stereoselective synthesis of cyclobutyl GABA analogues and related compounds from (-)-(S)-verbenone. Tetrahedron: Asymmetry, April 2002, vol. 13 , no. 5, p. 451-454.

PEREZ, Herminia I.; LUNA, Héctor; MANJARREZ, Norberto; SOLIS, Aida and NUÑEZ, Ma. Amelia. Preparation of (1S)-verbenone, aromatic and alicyclic carboxylic acids by oxidation of aldehydes, primary and secondary alcohols with Nocardia corallina. Biotechnology Letters, October 1999, vol. 21, no. 10, p. 855-858.

RAVID, Uzi; PUTIEVSKY, Eli; KATZIR, Irena; LEWINSOHN, Efraim and DUDAI, Nativ. Identification of $(1 R)(+)$-verbenone in essential oils of Rosmarinus officinalis L. Flavour and Fragrance Journal, March 1997, vol. 12 , no. 2 , p. 109-112.

RECH, Sandra B.; BATISTA, Cezar V.F.; SCHRIPSEMA, Jan; VERPOORTE, Robert and HENRIQUES, Amelia T. Cell cultures of Rauvolfia sellowii: growth and alkaloid production. Plant Cell, Tissue and Organ Culture, July 1998, vol. 54, no. 1, p. 61-63. 
ROUGE, Pablo D.; MOGLIONI, Albertina G.; MOLTRASIO, Graciela Y. and ORTUÑO, Rosa M. Stereoselective synthesis of chiral precursors to cyclobutane carbocyclic nucleosides and oligopeptides. Tetrahedron: Asymmetry, January 2003, vol. 14, no. 2, p. 193-195.

SCHENK, R.U. and HILDEBRANDT, A.C. Medium and Techniques for Induction and Growth of Monocotyledonous and Dicotyledonous Plant Cell Cultures. Canadian Journal Botanica, 1972, vol. 50, p. 199-204.

VAN DYK, M.S.; VAN RENSBURG, E. and MOLELEKI, N. Hydroxylation of (+)limonene, (-)-alpha-pinene and (-)b-pinene by a Hormonema sp. Biotechnology Letters, April 1998, vol. 20, no. 4, p. 431-436.

VANEK, Tomáš; HALÍK, Jan; VANKOVÁ, Radmila and VALTEROVÁ, Irena. Formation of trans-verbenol and verbenone from alpha-pinene catalysed by immobilized Picea abies cells. Bioscience, Biotechnology, and Biochemistry, February 2005, vol. 69, no. 2, p. 321-325.

WRIGHT, Susan J.; CAUNT, Philip; CARTER, David and BAKER, Peter B. Microbial oxidation of alpha-pinene by Serratia marcescens. Applied Microbiology and Biotechnology, January 1986, vol. 23, no. 3-4, p. 224-227. 